\title{
Floristic Composition of Woody Species and Potential Carbon Storage in Reforested Sites of Sudano-Sahelian Zone of Cameroon
}

\author{
${ }^{1}$ Souare Konsala ${ }^{*}{ }^{2}$ Abib Fanta Chimène, ${ }^{3}$ Wadjou Bruce Désiré, ${ }^{4}$ Ibrahima Adamou \\ ${ }^{1,2}$ University of Maroua, Faculty of Science, Department of Biological Sciences, P.O. Box: 814 Maroua \\ ${ }^{3}$ National Advanced School of Engineering of Maroua, P.O. Box: 46 Maroua \\ ${ }^{4}$ University of Ngaoundéré, Faculty of Science, Department of Biological Sciences, P.O. Box: 454 \\ Ngaoundéré
}

\begin{abstract}
The study examined the floristic diversity of woody species and their potential sequestration of carbon in reforested sites in sudano-sahelian zone of Cameroon. The experimental design was constituted of two blocks: Gaban and Matchoualta sites. In each block, a transect of $40000 \mathrm{~m} 2(1000 \mathrm{~m} \mathrm{x} 40 \mathrm{~m})$ was established. Four circular plots of $40 \mathrm{~m}$ of diameter were set up along the transect, and in each plot, all the woody individuals $(\mathrm{dbh} \geq 5 \mathrm{~cm}$ ) were inventoried. We used Origin 6.0 to perform the statistical analyses. Phytomass, storage and carbon credit of the woody individuals were estimated on the basis of allometric equations. A total of 3098 woody individuals was inventoried and distributed within 62 species, 46 genera and 26 families. Fifty-six species were recorded in Gaban and fourty-nine species in Matchoualta site. Phytomass and carbon storage were $263.20 \mathrm{t} / \mathrm{ha}$ and $131.6 \mathrm{tC} / \mathrm{ha}$ for Gaban site, $213.61 \mathrm{t} / \mathrm{ha}$ and $106.80 \mathrm{tC} / \mathrm{ha}$ for Matchoualta site. The CO2 equivalent amounts were $482.97 \mathrm{CO} 2 \mathrm{eq}$ and $391.97 \mathrm{CO}$ eq. The total economic values of the two reforested sites were $2624.82 \mathrm{\epsilon} / \mathrm{tCO} 2 \mathrm{eq} ; 4112.21 \mathrm{\epsilon} / \mathrm{tCO} \mathrm{eq}$ and 87 $794 \mathrm{\epsilon} / \mathrm{tCO} 2 \mathrm{eq}$ respectively for Clean Development Mechanism price, Voluntary carbon price and REDD+ price. Statistical analyses revealed that carbon stock values varied significantly between the two sites (ANOVA, $\mathrm{F}=81.80 ; \mathrm{P}=0.012$ ). The study provides valuable data useful for better management and monitoring of the two reforested sites with regard to tree carbon storage in mitigation of global warming and climate change.
\end{abstract}

Keywords: Woody Species, Reforested Sites, Carbon Storage, Sudano-Sahelian Zone, Cameroon.

\section{Introduction}

Carbon dioxide (CO2), one of the greenhouse gases, has been increasing in concentration due to anthropogenic activities worldwide, and elevates the earth's average temperature by greenhouse effect. Increase in temperature causes global warming and climate change. It has been predicted that the mean global temperature will increase by $1.1^{\circ} \mathrm{C}$ to $6.4^{\circ} \mathrm{C}$ by the year 2100 (IPCC 2007). Atmospheric carbon concentration was around $270 \mathrm{ppm}$ at the beginning of industrial revolution. It has crossed $400 \mathrm{ppm}$ by 2015 (NOAA 2015), and scientists have predicted that by 2070, carbon level will reach up to $500 \mathrm{ppm}$ (Jackson et al. 2015). Climate change due to increase in carbon emissions leads to great challenges for carbon mitigation strategies, besides socio-economic, biological problems and origin of new catastrophic diseases (Sicard and Dalstein-Richer 2015).

There is a strong interest in stabilizing the atmospheric abundance of $\mathrm{CO} 2$ and other GHGs to mitigate the risks of global warming (Kerr 2007, Kintisch 2007b, Kluger 2007, Walsh 2007). There are three strategies of lowering CO2 emissions to mitigate climate change (Schrag 2007): (i) reducing the global energy use, (ii) developing low or no-carbon fuel, and (iii) sequestering $\mathrm{CO} 2$ from point sources or atmosphere through natural and engineering techniques. Between 1850 and 1998, anthropogenic emissions were estimated at 270G30 Pg by fossil fuel combustion and at 136G30 Pg by land-use change, deforestation and soil cultivation (IPCC 2001). Presently, approximately $7 \mathrm{Pg} \mathrm{C}$ yr K-1 are emitted by fossil fuel combustion (Pacala and Socolow 2004) and 1.6 Pg C yr K-1 by deforestation, land-use change and soil cultivation. Of the total anthropogenic emissions of 8.6 Pg C yr K-1, 3.5 Pg C yr K-1 are absorbed by the atmosphere, 2.3 
Pg C yr K-1 by the ocean and the remainder by an unidentified terrestrial sink probably in the Northern Hemisphere (Tans et al. 1990, Fan et al. 1998).

Over the past two decades, some studies had been undertaken in assessing and estimating carbon stocks in agrosystems in Africa such as Zapfack et al. (2013, 2016), Mapongmetsem et al. (2011), Kemeuze et al. (2015), Jiagho et al. (2016), Noiha et al. (2017) and Ibrahima et al. (2019). None of these studies payed attention to the potential sequestration in the reforested sites put in place by the so-called "Green Sahel Operation" since 2008 in Cameroon. Though, these sites contributed much in restoring the soil and mitigating climate change in sudano-sahelian zone of Cameroon. However, very little is known about the processes of reforestation of defended savannas and carbon storage in the latter. Following the insights from previous research, we hypothesized that reforested savannas in sudano-sahelian zone of Cameroon are real carbon sinks, necessary in mitigation of global warming and climate change. The survey aimed at examining the floristic composition of woody species and their potential carbon sequestration in reforested savannas in sudano-sahelian zone of Cameroon in view of their better management and monitoring.

\section{Materials and Methods}

\subsection{Study Site}

The study was carried out in the Far- North Region of Cameroon, in the Mayo-Kani Division. The Division covers a total area of approximately $1785 \mathrm{~km}^{2}$ and a population of 42963 inhabitants (MINATD 2010). It is located between $10^{\circ} 0{ }^{\prime} 0^{\prime \prime} \mathrm{N}$ to $10^{\circ} 24^{\prime} 0^{\prime}{ }^{\prime} \mathrm{N}$ and $14^{\circ} 12^{\prime} 0^{\prime}$ ' $\mathrm{E}$ to $14^{\circ} 36^{\prime} 0^{\prime}$ ' $\mathrm{E}$ (Figure 1). The two reforested sites chosen for this study cover approximately 1000 ha (i.e. 500 ha each). The climate is of the Sudano-sahelian zone and is characterized by two seasons, a long dry season (8 to 9 months) spanning from October to May and a short rainy season (3 to 4 months) from June to September (Fotsing 2009). Very high temperatures reaching $45^{\circ} \mathrm{C}$ under shade and a very dry atmosphere are experienced from March to June (MINATD 2010). Rainfall varies between 600 and $900 \mathrm{~mm} /$ year, with maximum rainfall mostly between July and August (Djibrilla 2016). Hydrography is made up of temporal flowing rivers (Mayos) which dry up at the end of the rainy season. The main soil types encountered are vertisols, hardés, sandy soils, rocky soils in mountain areas, and silty soils favorable to market gardening (FAO 2011).

The vegetation is characterized by a shrub steppe of the Sudano-Sahelian type. The most popular plant species are: Adansonia digitata, Khaya senegalensis, Tamarindus indica, Acacia albida, Acacia spp., Ziziphus mauritiana and Ficus spp. Most of these plants are used for livestock feed (Wafo 2008). Other African mistletoe and Acacia albida are appreciated for their leaves serving as fodders and their fertilizing roots. Fertile soils are indicated by the presence of Acacia albida (Djibrilla 2016). The wildlife is poor and is endangered due to the lack of a conducive environment for their development. Some species are mostly located in the mountains, and include rodents (mice, rats, damans, squirrels, hares); reptiles (lambs, lizards, snakes); locusts and caterpillars; sparrows; hyenas; panthers and wild cats; monkeys (IPCC 2007). Most of the people rely on agriculture, livestock and forest resources to meet their basic needs.

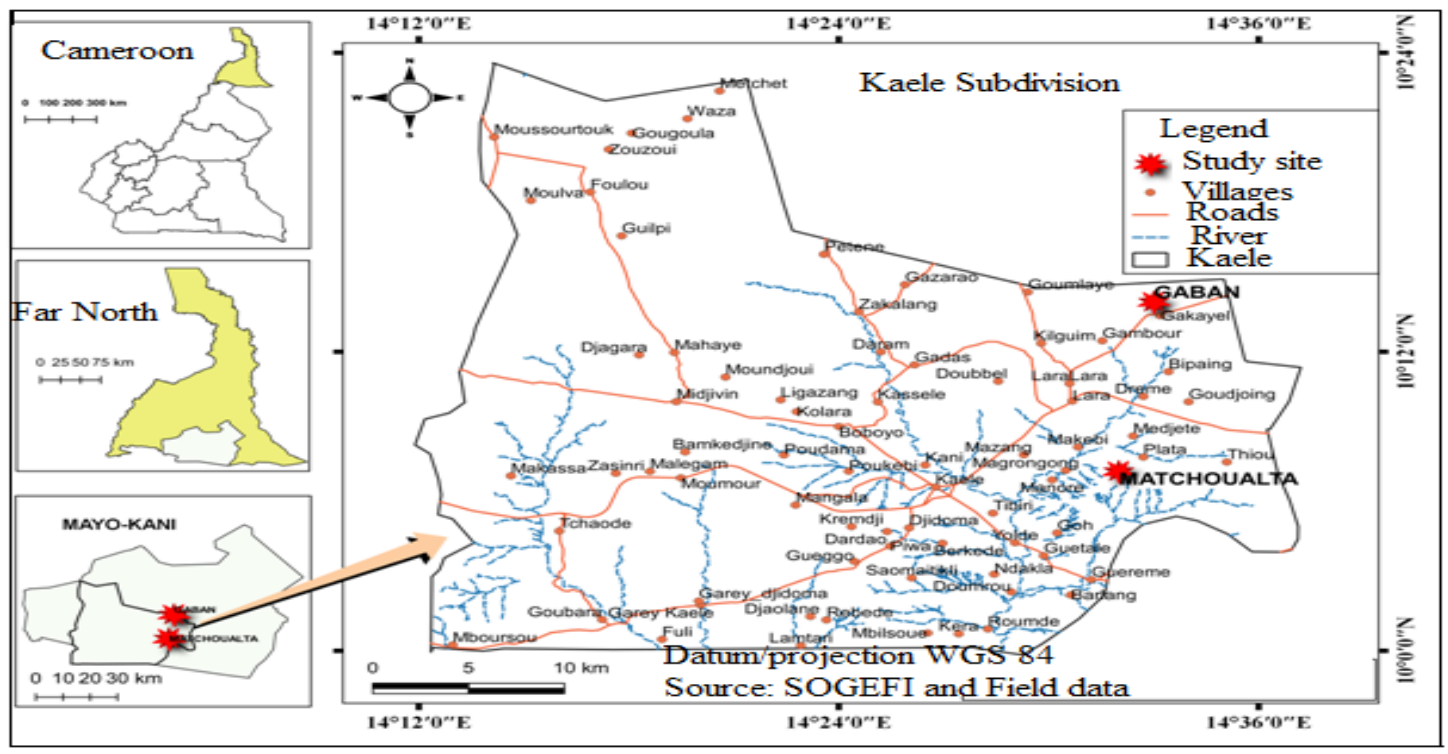




\subsection{Data collection}

\subsubsection{Inventory of woody species of the reforested sites}

The transect method (Lejoly 1993), and circular plot method (Diabate et al. 2007) were used for the inventory of the woody species in the reforested sites of Gaban and Matchoualta. A transect of $40000 \mathrm{~m} 2(1$ $000 \mathrm{~m} \times 40 \mathrm{~m}$ ) was established in each site, and five (05) circular plots of $40 \mathrm{~m}$ of diameter each were set up along the transect. In each circular plot, all the woody individuals $(\mathrm{dbh} \geq 10 \mathrm{~cm})$ were inventoried and measured at $1.30 \mathrm{~m}$ in a radius of $20 \mathrm{~m}$ and those of $\mathrm{dbh} \geq 5 \mathrm{~cm}$ in a radius of $10 \mathrm{~m}$ (Figure 2). Woody individuals that plug in before $1.30 \mathrm{~m}$ in height were measured at $10 \mathrm{~cm}$ from the ground (Jiagho et al. 2016). The height of trees was estimated using a graduated pole and the circumference measured using a measuring tape.

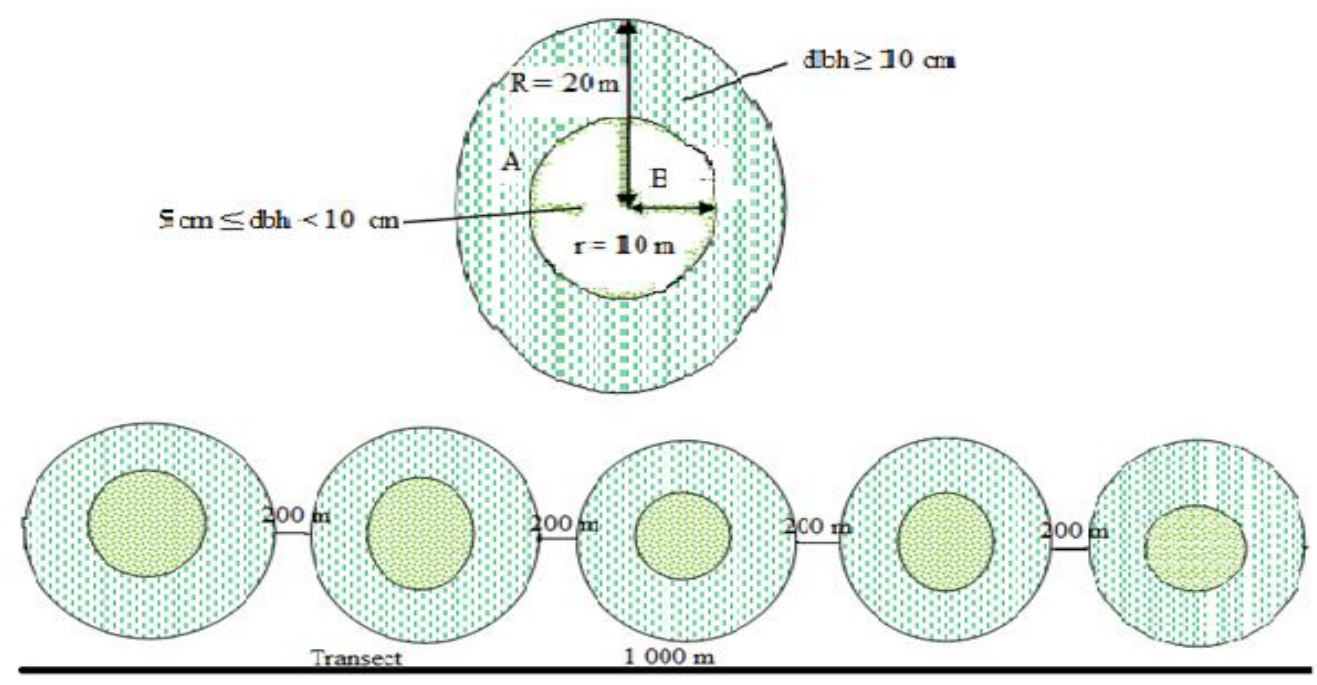

Figure 2: Experimental design for floristic inventory

\subsubsection{Estimation of biomass and carbon sequestration of woody species in the reforested sites}

The total biomass of standing woody plants is constituted of the Above Ground Biomass (AGB) and Below Ground Biomass (BGB). We used the non-destructive method to evaluate the biomass. The AGB was estimated with the allometric model developed by Djomo et al. (2010) for dry forest of tropical Africa and the BGB with the method developed by the IPCC (2006). Carbon stock of each tree was calculated as $50 \%$ of its biomass following Mohanraj et al. (2011) and Timilsina et al. (2014).

\subsection{Data processing and analysis}

Diversity of tree species was assessed with Shannon-Weaver diversity index (H') (Magurran 2004) and Shannon's Evenness index (EQ). Diversity index takes into account not only the number of species but also whether species are more or less equally abundant, or whether in contrast one or a few species dominate.

$\mathrm{H}^{\prime}=-\Sigma \mathrm{Ni} / \mathrm{N} \log 2 \mathrm{Ni} / \mathrm{N}$, where $\mathrm{H}^{\prime}=$ index of species diversity, $\mathrm{Ni}=$ number of individuals of a given species i, $\mathrm{N}=$ total number of individuals, $\log 2=\operatorname{logarithm}$ in basis 2 .

$\mathrm{EQ}=\mathrm{H}^{\prime} / \log 2 \mathrm{~N}$, this index varies from 0 to 1 .

Family importance value index (FIV) values (Mori et al. 1983) were also calculated:

Relative frequency $=$ (frequency of a species/sum of all frequencies $) \times 100$

Family relative diversity $=$ (number of species in a family/total number of species $) \times 100$

FIV = family relative diversity + relative density + relative dominance

Relative dominance $=($ basal area of a species/basal area of all the species $) \times 100$

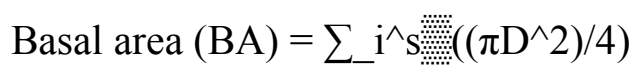


Where D: diameter of tree at $1.30 \mathrm{~m} ; \pi=3.141593$

The estimation of Above Ground Biomass (AGB) was performed by using the mathematical model of Djomo et al. (2010) with the following formula:

$\mathrm{AGB}=\exp (-2.29016+0.1651(\operatorname{lnD}) 2+0.6620 \ln (\mathrm{D} 2 \mathrm{H})+0.1309 \ln \rho)$

Where $\rho=$ specific density of the wood $(\mathrm{g} / \mathrm{cm} 3)$ which corresponds to $0.58 \mathrm{~g} / \mathrm{cm} 3$ for species with unknown density (Brown et al. 1997); $\mathrm{H}=$ height $(\mathrm{m}) ; \mathrm{D}=$ diameter.

The Below Ground Biomass was calculated by using the following formula:

$\mathrm{BGB}=\mathrm{AGB} \times \mathrm{R}$, where $\mathrm{R}$ is the ration stem/root, $\mathrm{R}=0.24$ (IPCC 2006).

The carbon storage was calculated by the following formula:

$\mathrm{CS}=\mathrm{TB} \times 0.5$, where $\mathrm{CS}(\mathrm{tC} / \mathrm{ha})$ is the carbon storage; $\mathrm{TB}(\mathrm{AGB}+\mathrm{BGB})$ is the total biomass $(\mathrm{t} / \mathrm{ha})$ and 0.5 is a constant (IPCC 2003, Timilsina et al. 2014).

The CO2 equivalent was calculated using the following formula:

CO2eq = CS x 3.67 (IPCC 2006).

Given the economic stakes linked to the carbon stock, we have estimated the financial cost of the carbon content in the reforested sites. Several markets of carbon are put in place since the years 2000. We opted for the Clean Development mechanism (CDM) price, Voluntary market price and REDD+ price. The average selling price of the forest credit is $3 \mathrm{\epsilon} / \mathrm{tCO} 2 \mathrm{eq}$ for the CDM price; $4.7 \mathrm{\epsilon} / \mathrm{tCO} 2 \mathrm{eq}$ for the voluntary market price and $100 \mathrm{\epsilon} / \mathrm{tCO} 2 \mathrm{eq}$ (high value) for the REDD+ price (Chenost et al. 2010).

Analysis of variance (ANOVA) was used to compare the means of carbon stock values between the two reforested sites. The statistical analysis was performed with Origin 6.0 Software.

\section{RESULTS}

\subsection{Diversity of the reforested sites}

In total, 3098 trees $(\mathrm{dbh} \geq 5 \mathrm{~cm})$ were inventoried and distributed within 62 species, 46 genera and 26 families (Table 1). All the trees were identified at the level of species which varied from 49 to 56 species for Gaban site and Matchoualta site respectively. The Shannon diversity index $\left(\mathrm{H}^{\prime}\right)$ was moderate in the two reforested sites, $\mathrm{H}^{\prime}=3.8$ bits and 3.2 bits respectively for Gaban site and Matchoualta site. The Shannon evenness index (EQ) values were $\mathrm{EQ}=0.49$ for Gaban site and $E Q=0.42$ for Matchoualta site. The Gaban site was more diversified than Matchoualta site with 56 species and 49 species respectively. The means of diversity between the two sites were not significantly different (ANOVA, $\mathrm{P}=0.88$ ).

\section{Table 1: Number of taxa and diversity indices of the reforested sites}

\begin{tabular}{|l|l|l|l|}
\hline Parameters & Gaban site & Matchoualta site & Total \\
\hline Number of individuals & 1702 & 1396 & 3098 \\
\hline Number of family & 23 & 21 & 26 \\
\hline Number of genera & 43 & 41 & 46 \\
\hline Number of species & 56 & 49 & 62 \\
\hline H' (bits) & 3.8 & 3.2 & 3.6 \\
\hline EQ & 0.49 & 0.42 & 0.47 \\
\hline
\end{tabular}

\subsection{Floristic composition of the two reforested sites}

The seven most important families (those of the highest values of FIV index) represented less than $30 \%$ of all families, but accounted for $79.83 \%$ of the total FIV within the two sites. These families with the highest FIV and number of individuals were Mimosaceae (74.66), Combretaceae (71.33), Caesalpiniaceae (36.21), Moraceae (29.10), Meliaceae (20.8), Fabaceae (14.40) and Anacardiaceae (13.5). The most species-rich 
families were Mimosaceae (13 species), Caesalpiniaceae (08 species) and Combretaceae (07 species) (Table 2). Combretaceae and Mimosaceae owed their high FIV index to their abundance, contributing mostly to the understory with numerous individuals.

Table 2: Family importance value (FIV) of the most important families within the two reforested sites. The bold indicates the most important families. Dr: relative density; DR: relative dominance; Fr: relative frequency; FIV: family importance value.

\begin{tabular}{|c|c|c|c|c|c|}
\hline Family & Species & Dr & DR & $\mathbf{F r}$ & FIV \\
\hline \multirow[t]{4}{*}{ Anacardiaceae } & Anacardium occidentale L. & & & & \\
\hline & Lannea acida A. Rich. & & & & \\
\hline & $\begin{array}{l}\text { Lannea schimperi (Hochst. ex A. } \\
\text { Rich.) Engl. }\end{array}$ & 5.0 & 4.4 & 4.1 & 13.5 \\
\hline & $\begin{array}{l}\text { Sclerocarya birrea (A. Rich.) } \\
\text { Hochst. }\end{array}$ & & & & \\
\hline \multirow[t]{2}{*}{ Annonaceae } & Annona senegalensis Pers. & & & & \\
\hline & $\begin{array}{l}\text { Hexalobus monopetalus (A. Rich.) } \\
\text { Engl. \& Diels. }\end{array}$ & 2.7 & 2.9 & 2.1 & 7.7 \\
\hline Burseraceae & Boswellia dalzielii Hutch. & 1.6 & 1.8 & 1.5 & 4.9 \\
\hline Bombacaceae & Adansonia digitata $\mathrm{L}$. & 0.9 & 0.7 & 1.0 & 2.6 \\
\hline \multirow{8}{*}{ Caesalpiniaceae } & Afzelia africana Smith ex Pers. & & & & \\
\hline & Cassia arereh Del. & & & & \\
\hline & Delonix regia (Boj.) Raf. & & & & \\
\hline & $\begin{array}{l}\text { Detarium microcarpum Guill. \& } \\
\text { Perr. }\end{array}$ & & & & \\
\hline & $\begin{array}{l}\text { Piliostigma reticulatum (DC.) } \\
\text { Hochst. }\end{array}$ & 13.2 & 11.51 & 11.5 & 36.21 \\
\hline & $\begin{array}{l}\text { Piliostigma thonningii (Schumach.) } \\
\text { Milne-Redh. }\end{array}$ & & & & \\
\hline & $\begin{array}{l}\text { Senna siamea (Lam.) Irwin. \& } \\
\text { Barneby }\end{array}$ & & & & \\
\hline & Tamarindus indica L. & & & & \\
\hline Capparidaceae & Capparis sepiaria $\mathrm{L}$ & 0.5 & 0.5 & 0.4 & 1.4 \\
\hline Celastraceae & Maytenus senegalensis (Lam.) Exell. & 0.2 & 0.2 & 0.2 & 0.6 \\
\hline \multirow{6}{*}{ Combretaceae } & $\begin{array}{l}\text { Anogeissus leiocarpus (DC.) Guill. } \\
\text { \& Perr. }\end{array}$ & & & & \\
\hline & Combretum aculeatum Vent. & & & & \\
\hline & Combretum glutinosum Perr. ex DC. & & & & \\
\hline & Combretum micranthum G. Don & 23.10 & 23.73 & 24.50 & 71.33 \\
\hline & $\begin{array}{l}\text { Combretum nigricans Lepr. ex Guill. } \\
\text { \& Perr. }\end{array}$ & & & & \\
\hline & Guiera senegalensis G.F. Gmel. & & & & \\
\hline
\end{tabular}




\begin{tabular}{|c|c|c|c|c|c|}
\hline & $\begin{array}{l}\text { Terminalia macroptera Guill. \& } \\
\text { Perr. }\end{array}$ & & & & \\
\hline Ebenaceae & $\begin{array}{l}\text { Diospyros mespiliformis } \text { Hochst. ex } \\
\text { A. Rich. }\end{array}$ & 0.6 & 0.6 & 0.6 & 1.8 \\
\hline Euphorbiaceae & Bridelia scleroneura Müll. Arg. & 0.3 & 0.3 & 0.2 & 0.8 \\
\hline \multirow[t]{2}{*}{ Fabaceae } & Andira inermis (Wrigt) DC. & 4.1 & 5.1 & 5.2 & 14.40 \\
\hline & $\begin{array}{l}\text { Dalbergia melanoxylon Guill. \& } \\
\text { Perr. }\end{array}$ & & & & \\
\hline Hymenocardiaceae & Hymenocardia acida Tul. & 0.1 & 0.1 & 0.2 & 0.4 \\
\hline \multirow[t]{2}{*}{ Meliaceae } & Azadirachta indica A. Juss. & 7.2 & 7.1 & 6.5 & 20.8 \\
\hline & Khaya senegalensis (Desr.) A. Juss. & & & & \\
\hline \multirow{13}{*}{ Mimosaceae } & Acacia albida Del. & & & & \\
\hline & Acacia ataxacantha DC. & & & & \\
\hline & Acacia gerrardii Benth. & & & & \\
\hline & Acacia laeta $\mathrm{R}$. Br. ex Benth. & & & & \\
\hline & Acacia nilotica (L.) Willd. ex Del. & & & & \\
\hline & Acacia polyacantha Willd. & & & & \\
\hline & Acacia Senegal (L.) Willd & & & & \\
\hline & Acacia seyal Del. & 25.1 & 24.56 & 25.0 & 74.66 \\
\hline & Albizia chevalieri Harms. & & & & \\
\hline & $\begin{array}{l}\text { Dichrostachys cinerea }(\mathrm{L} .) \text { Wright } \& \\
\text { Arn. }\end{array}$ & & & & \\
\hline & Entada africana Guill. \& Perr. & & & & \\
\hline & $\begin{array}{l}\text { Parkia biglobosa (Jacq.) R. Br. ex G. } \\
\text { Don }\end{array}$ & & & & \\
\hline & $\begin{array}{l}\text { Prosopis africana (Guill. \& Perr.) } \\
\text { Taub. }\end{array}$ & & & & \\
\hline \multirow{3}{*}{ Moraceae } & Ficus platyphylla Del. & & & & \\
\hline & Ficus polita Vahl. & 8.5 & 10.3 & 10.3 & 29.10 \\
\hline & Ficus Thonningii Blume & & & & \\
\hline Myrtaceae & Eucalyptus camaldulensis Dehnh. & 2.2 & 1.8 & 1.7 & 5.7 \\
\hline Olacaceae & Ximenia americana $\mathrm{L}$. & 0.8 & 0.7 & 0.7 & 2.2 \\
\hline Palmae & Borassus aethiopum Mart. & 0.3 & 0.2 & 0.3 & 0.8 \\
\hline Rhamnaceae & Ziziphus mauritiana Lam. & 0.4 & 0.3 & 0.5 & 1.2 \\
\hline \multirow[b]{3}{*}{ Rubiaceae } & Feretia apodanthera $\mathrm{L}$. & & & & \\
\hline & Gardenia aqualla Stapf. \& Hutch. & 1.1 & 1.0 & 1.2 & 3.3 \\
\hline & $\begin{array}{l}\text { Gardenia ternifolia Schumach. \& } \\
\text { Thonn. }\end{array}$ & & & & \\
\hline
\end{tabular}




\begin{tabular}{|l|l|l|l|l|l|}
\hline Sapotaceae & Vitellaria paradoxa Gaertn. f. & 0.2 & 0.1 & 0.3 & 0.6 \\
\hline Sterculiaceae & Sterculia setigera Del. & 0.2 & 0.1 & 0.2 & 0.5 \\
\hline Tiliaceae & Grewia venusta Fresen & 0.1 & 0.1 & 0.2 & 0.4 \\
\hline \multirow{2}{*}{ Ulmaceae } & Celtis integrifolia Lam. & 0.2 & 0.1 & 0.2 & 0.5 \\
\hline Verbenaceae & Vitex doniana Sweet & 0.3 & 0.3 & 0.3 & 0.9 \\
\cline { 2 - 7 } & Vitex simplicifolia Oliv. & & & & \\
\hline Tygophyllaceae & Balanites aegyptiaca L. & 1.1 & 1.1 & 1.1 & 3.3 \\
\hline
\end{tabular}

2.3. Biomass, carbon stock, carbon equivalent and economic values of woody species in the reforested sites

The reforested site of Gaban recorded 263.20 t/ha of total biomass and Matchoualta site recorded 213.61 t/ha (Table 3). The total biomass in the two reforested sites was $476.81 \mathrm{t} / \mathrm{ha}$. Gaban site recorded the most important carbon storage and carbon equivalent $(\mathrm{CS}=131.6 \mathrm{tC} / \mathrm{ha} ; 482.97 \mathrm{CO}$ eq). Means of carbon storage and carbon equivalent in the two reforested sites were significantly different (ANOVA, F $=45.54 ; \mathrm{P}$ $=0.02$ ). As far as the economic stake linked to the carbon storage is concerned, the total of economic values of the two reforested sites was $2624.82 \mathrm{\epsilon} / \mathrm{tCO} 2 \mathrm{eq} ; 4112.21 \mathrm{\epsilon} / \mathrm{tCO} 2 \mathrm{eq}$ and $87794 \mathrm{\epsilon} / \mathrm{tCO} 2 \mathrm{eq}$ respectively for Clean Development Mechanism (CDM) price, Voluntary market price and REDD+ price (Table 3).

Table 3: Total biomass, carbon stock, carbon equivalent and economic value in the two reforested sites. CDM: Clean Development Mechanism; REED+: Reducing Emissions from Deforestation and Forest Degradation; CO2eq: Carbon equivalent

\begin{tabular}{|c|c|c|c|c|c|c|}
\hline \multirow{2}{*}{$\begin{array}{l}\text { Reforested } \\
\text { sites }\end{array}$} & \multirow{2}{*}{$\begin{array}{l}\text { TB } \\
(\mathbf{t} / \mathbf{h a})\end{array}$} & \multirow{2}{*}{$\begin{array}{l}\text { Carbon } \\
\text { stock } \\
\text { (tC/ha) }\end{array}$} & \multirow{2}{*}{$\begin{array}{l}\mathrm{CO}_{2} \mathbf{e q} \\
(\mathrm{t} / \mathrm{ha})\end{array}$} & \multicolumn{3}{|c|}{ Economic value (Euro) } \\
\hline & & & & CDM carbon price & Voluntary carbon market & REDD+ market \\
\hline Gaban & 263.2 & 131.6 & 482.97 & 1448.91 & 2269.95 & 48297 \\
\hline Matchoualta & 213.61 & 106.8 & 391.97 & 1175.91 & 1842.25 & 39197 \\
\hline Total & 476.81 & 238.4 & 874.94 & 2624.82 & 4112.21 & 87794 \\
\hline
\end{tabular}

3. Discussion

\subsection{Tree diversity and floristic composition of the two reforested sites}

The two reforested sites, Gaban and Matchoualta sites in the soudano-sahelian zone of Cameroon, showed different values of Shannon-Weaver (H') and evenness index (EQ) (Table 1). Forest communities considered rich are characterized by a Shannon diversity value of about 3.5 bits or higher (Kent and Coker 1992). As such, Gaban reforested site could be considered rich $\left(\mathrm{H}^{\prime}=3.8\right.$ bits) and Matchoualta reforested site moderate $\left(\mathrm{H}^{\prime}=3.2\right.$ bits $)$. The moderate and the higher diversity Shannon in these reforested sites seems to be derived from moderate anthropogenic activities at that level. These values in savannah indicates a relative stability and maturity in the sites for the experimental year. The moderate evenness values observed in the sites $(E Q=0.49$ and 0.42$)$ respectively for Gaban and Matchoualta sites indicates also their level of maturity.

The most important families in terms of family importance value (FIV) (Table 2) were Mimosaceae (74.66), Combretaceae (71.33), Caesalpiniaceae (36.21) and Moraceae (29.10). The importance of these families in the study site is due to the fact that drought in the Sahel has allowed natural selection of the most robust species like in these families. Similarly, the surveys conducted in African savannahs and more typical in sudano-sahelian zones of Burkina-Faso and Cameroon (Bognounou et al. 2009; Froumsia et al. 2012) stated that these families are resistant to the lack and insufficient rains but also to high temperatures. Moreover, 
they are the most common and highly represented in tropical countries. Moreover, the higher regeneration potential of those families is due to maximum seed dispersal capability (Jannat et al. 2020) and favorable conditions prevailing for natural regeneration.

\subsection{Biomass, carbon storage and economic value of the reforested sites}

Woody biomass varies according to the plant communities (Baccini et al. 2008; Fayolle et al. 2013). We found that quantity of biomass in the two reforested sites was $222.40 \pm 8.79 \mathrm{t} / \mathrm{ha}$ on the average. This value is higher than the average quantity recognized by IPCC (2006) on the altitudes upper than $1500 \mathrm{~m}$, that's 169 $\mathrm{t} / \mathrm{ha}$ on the basis of remote detection. This variability is due to the floristic composition and the vegetation structure in such a way that our sites which were reforested by exotic plants got great quantity of phytomass. The planted species were Azadirachta indica, Acacia nilotica, Dalbergia melanoxylon, Khaya senegalensis, Eucalyptus camaldulensis and Cassia siamea. When the vegetation becomes heterogeneous (Imani et al. 2016), the richness at the same time increases and promotes an increase in value total anatomical density of species per hectare.

The two reforested sites got $119.2 \pm 12.4 \mathrm{tC} / \mathrm{ha}$ on the average. This value is less than $154.85 \mathrm{tC} / \mathrm{ha}$ which was obtained by Ibrahima et al. (2019) in 20-year fallow in the sudano-guinean savannahs of Ngaoundéré in Cameroon. The same authors stated that old fallows over the age of 25 could accumulate between 64 and $131 \mathrm{tC} / \mathrm{ha}$ more than young fallows of less than 5 years old $(5-20 \mathrm{tC} / \mathrm{ha})$. Our sites were enriched with plantations 12 years ago during the "Green Sahel Operation" lead by the Ministry of Youth and Sports in 2008. This value was also less than the results obtained in tropical rain forest, New Guinea (164.45 tC/ha) (Enright 1979) and in tropical rain forest at Khade, Ghana (152.84 tC/ha) (Greenland and Gowel 1970). The variation in carbon storage among the woody sites can be influenced by different factors such as leaf traits, microclimate and edaphic characteristics. Scientists have proved that forest types can alter soil organic carbon stock through several factors, including litter inputs through litter fall, root turnover, litter quality and soil chemistry (Wang et al. 2010). These above factors can indirectly affect vegetation carbon stock that varies in magnitude with varying forest types. The two reforested sites in our study site are therefore a carbon sink and will further store more carbon atmospheric and thus contribute to the mitigation of the greenhouse effect.

The monetary value varied from 2624.82 to $87794 \mathrm{\epsilon} / \mathrm{tCO} 2 \mathrm{eq}$ in total according to markets (Table 3). This result falls out of the medium of the range of 2108.08 and $5828.22 \mathrm{\epsilon} / \mathrm{tCO} 2 \mathrm{eq}$ found in the Depka reserve in Ivory-Coast (Anonymous, 2015). Natural woody spaces sequester more carbon than planted forests (Dubé ét al. 2004) though these last ones are well entertained. Yet, these natural woody spaces could store more carbon when they are enriched by plantings. The reforested sites of this study were rather enriched by other tree species.

\section{Conclusion}

A study on the floristic composition and the potential of carbon sequestration by woody species was undertaken in two reforested sites in the Sudano-Sahelian zone of Cameroon. The examination of the floristic composition carried out during the floristic and dendrometric inventories revealed 3098 woody individuals $(\mathrm{dbh} \geq 5 \mathrm{~cm})$ distributed in 62 species, 46 genera and 26 families. Mimosaceae, Combretaceae and Caesalpiniaceaea were the most important families in terms of FIV. Gaban site sequestered more carbon than Matchoualta site. Means of carbon storage and carbon equivalent in the two reforested sites were significantly different (ANOVA, $\mathrm{F}=45.54 ; \mathrm{P}=0.02$ ). The total carbon credit in the reforested sites varied from $2624.82 \mathrm{\epsilon} / \mathrm{tCO} 2 \mathrm{eq}$ to $87794 \mathrm{\epsilon} / \mathrm{tCO} 2 \mathrm{eq}$ according to the types of markets. The two reforested sites are therefore a carbon sink and will further store more carbon atmospheric and thus contribute to the mitigation of the greenhouse effect. More efforts are required to enrich the sites with more operations of planting species in sudano-sahelian domain of Cameroon.

\section{Acknowledgements}

The authors thank the top management of the Regional Delegation of the Ministry of Environment, Nature Protection and Sustainable Management of Cameroon for their contribution for the realization of this study.

\section{Conflicts Of Interest}

There's no conflict of interest. 


\section{Authors' Contributions}

Souare Konsala and Wadjou Bruce Désiré carried out the study and developed the manuscript. The other authors made comments to improve the final manuscript.

\section{References}

[1.] Awe DV, Noiha NV, Zapfack L, Vroh BTA and Saïdou A (2019) Carbon Sequestration Potential and Economic Value in Agroforestry Parkland to Tectona grandis L.f. (Verbenaceae) in Central Africa: A Case Study to Department of Poli (Northern Region in Cameroon). Advances in Research 18(5): 1-16.

[2.] Baccini A, Laporte N, Goetz SJ, Sun M, Dong H (2008) A first map of tropical Africa's aboveground biomass derived from satellite imagery. Environ. Res. Lett., 3, 1-9. doi:10.1088/17489326/3/4/045011.

[3.] Bognounou F, Thiombiano A, Savadogo P, Boussim JI, Odén PC, Guinko S (2009) Woody vegetation structure and composition at four sites along latitudinal gradient in Western Burkina Faso. Bois et Forêts des Tropiques, 300: 29-44. DOI : 10.19182/bft2009.300.a20412.

[4.] Brown S, Gilespie AJR, Lugo AE (1997) Biomass estimation methods for tropical forest with application to forest inventory data. Forest Sciences 35(4): 881-902.

[5.] Chenost C, Gardette Y, Demenois J, Grondard N, Perrier M, Wemaere M (2010) Bringing forest carbon projects to the market. UNEP-ONFI-AFD-BioCF. $172 \mathrm{p}$.

[6.] Diabaté M, Lamanda N, Wagler C, Malézieux E, de Foresta H (2007) Farmers'contribution to the conservation of biodiversity: the coffee-based agroforestry systems in «Guinée Forestière» (Guinea, West Africa). International Symposium on Multistrata Agroforestry Systems with Perennial Crops", CATIE, Turrialba, Costa-Rica, 17-21 September 2007.

[7.] Djibrilla, M. (2016) : Etude de la vulnérabilité de la biodiversité végétale ligneuse dans la zone soudano-sahélienne du Cameroun: cas du Département du Mayo-Kani (Canton de Lara). Mémoire de Master en Biologie des Organismes Végétaux, Université de Ngaoundéré, $80 \mathrm{p}$

[8.] Djomo AN, Ibrahima A, Saborowski J, Gravenhorst G (2010) Allometric equations for biomass estimations in Cameroon and pan moist tropical equations including biomass data from Africa. Forest Ecology and Management 260: 1873-1885. DOI:10.1016/j.foreco.2010.08.034

[9.] Dubé A, Saint-Laurent D, Senécal G (2006) Penser le renouvellement et la politique de conservation de la forêt urbaine à l'ère du réchauffement climatique. Métropoles Nature, Projet d'étude sur les métropoles, l'environnement et la nature en ville. Rapport préliminairere, ICI Environnement. $50 \mathrm{p}$.

[10.] Enright NJ (1979) Litter production and nutrient partitioning in rain forests near Bulolo, Papua New Guinea. Malaysian Forester 42:202-220.

[11.] Fan, S., Gloor, M., Mahlman, J., Pacala, S., Sarmiento, J., Takahashi, T. \& Tan, P. 1998 A large terrestrial carbon sink in North America implied by atmospheric and oceanic carbon dioxide data and models. Science 282 : 442-446. DOI: 10.1126/science.282.5388.442).

[12.] FAO (2011) Les forêts au service de la nutrition et de la sécurité alimentaire. Etude FAO, Rome. $10 \mathrm{p}$.

[13.] Fayolle A, Doucet JL, Gillet JF, Bourland N, Lejeune P (2013) Tree allometry in Central Africa: Testing the validity of pantropical multi-species allometric equations for estimating biomass and carbon stocks. Forest Ecology and Management 305 : 29-37. DOI: 10.1016/j.foreco.2013.05.036.

[14.] Fotsing E (2009) Small Savannah: Un système d'information pour l'analyse intégrée des changements d'utilisation de l'espace à l'Extrême-Nord, Cameroun. Thèse de Doctorat/ Ph.D, Université de Wageningen, Pays-Bas. 373 p.

[15.] Froumsia M, Zapfack L, Mapongmetsem PM, Nkongmeneck BA (2012) Woody species, composition, structure and diversity of vegetation of Kalfou Forest reserve, Cameroon. Journal of Ecology and the Natural Environment 4(13): 333-343. DOI: 10.5897/JENE12.047.

[16.] Greenland GJ, Gowel JML (1970) Nutrient content of the moist tropical forests of Guana. Plant Science 12:154-174.

[17.] Ibrahima A, Nguilandi SP, Abib FC (2019) Carbon stock as related to fallow age in the sudanoguinea savannah of Ngaoundéré, Adamawa, Cameroon. International Journal of Plant and Soil Science 27(2): 1-14. DOI: 10.9734/IJPSS/2019/v27i230074. 
[18.] Imani MG, Zapfack L, Mangambu MJD, Penedimanja P, Mwanga MIJC, Boyemba F, Amani C 2016 Caractérisations structurale, floristique et biomasse ligneuse du peuplement à Hagenia abyssinica du parc national de Kahuzi-Biega (Rift Albertin, RDC). European Scientific Journal 12(15) : 189-209.

[19.] IPCC (2001) Climate change 2001: the scientific basis intergovernmental panel on climate change. Cambridge, UK: Cambridge University Press.

[20.] IPCC (2003) Recommandations en matière de bonnes pratiques pour le secteur de l'utilisation

[21.] des terres, changements d'affectation des terres et foresterie. IPCC/UNEP/WMO, Hayama, Kanagawa, Japan. 307 p.

[22.] IPCC (2006) Terres forestières: Agriculture, foresterie et autres affectations des terres. Lignes directrices 2006 du GIEC pour les inventaires nationaux de gaz à effet de serre. $93 \mathrm{p}$

[23.] IPCC (2007) Groupe de travail I du GIEC : Quatrième Rapport d'évaluation, Bilan 2007 des changements climatiques les bases scientifiques physiques, Résumé à l'intention des décideurs, $25 \mathrm{p}$

[24.] Jackson RB, Jobbagy E, Avissar R, Baidya RS, Barrett D, Cook CW, Farley KA, Le Maitre DC, Mc Carl BC, Murray BC (2005) Trading water for carbon with biological carbon sequestration.Science310, 1944-1947. DOI:10.1126/science.1119282.

[25.] Jannat M, Kamruzzaman M, Kamal Hossain M (2020) Assessment of natural regeneration potential of native tree species in a community management forest of Bangladesh. International Journal of Environment, 9(1): 100-114. DOI: https://doi.org/10.3126/ije.v9i1.27598.

[26.] Jiagho ER, Zapfack L, Kabelong BLPR, Tsayem D, Corbonnois J, Tchawa P (2016) Diversité de la flore ligneuse à la périphérique du Parc National de Waza (Cameroun). Revue des Sciences Environnementales 6(1): 1-32. DOI: https://doi.org/10.4000/vertigo.17249.

[27.] Kemeuze VA, Mapongmetsem PM, Sonwa D, Fongnzossie FE, Nkongmeneck BA (2015) Plant diversity and carbon stock in sacred groves of semi-arid areas of Cameroon: case study of Mandara Mountains. International Journal of Environment 4(2): 308-318. DOI: 10.3126/ije.v4i2.12659.

[28.] Kent M, Coker P (1992) Vegetation description and analysis. A practical approach, New York: John Wiley and Sons. 363 p.

[29.] Kerr RA (2007) Scientists tell policy makers we're all warming the world.Science315, 754-757. DOI: $10.1126 /$ science.315.5813.754.

[30.] Kintisch E (2007b) New congress may be warming up to plans for capping emissions. Science 315, 444. DOI: $10.1126 /$ science.315.5811.444)

[31.] Kluger J (2007) Global warming: what now? Our feverish planet badly needs a cure. Time Magazine 9. pp 50-109.

[32.] Lejoly J (1993) Méthodologie pour les inventaires forestiers (partie flore et végétation) Rapport ECOFAC. Agreco/Cirad-Forêt, Montpellier, France. 53 p.

[33.] Magurran AE (2004) Measuring biological diversity. Blackwell Publishing: Oxford, UK p. 256.

[34.] MINADT (2010): Enquête agricole au Cameroun. Manuel d'instruction aux agents recenseurs. $45 \mathrm{p}$.

[35.] Mohanraj R, Saravanan J, Dhanakumar S (2011) Carbon stock in Kolli forests, Eastern Ghats (India) with emphasis on aboveground biomass, litter, woody debris and soils. Forest 4:61-65.

[36.] NOAA (2015) National oceanic and atmospheric administration, US. http://www.esrl.noaa.gov/gmd/ccgg/trends/.Mori, S.A., Boom, B.M,, Carvalino, A.M. and Dos Santos, T.S., 1983. The ecological importance of Myrtaceae in an eastern Brazilian wet forest. Biotropica, 15:68-70.

[37.] Noiha NV, Zapfack L, Awé DV, Witanou N, Nyeck B, Ngossomo JD, Hamadou MR, Chimi CD, Tabue MRB (2017) Floristic structure and sequestration potential of cashew agroecosystems in Africa: A case study from Cameroon. Journal of Sustainable Forestry 36(3): 277-288

[38.] Pacala S, Socolow R (2004) Stabilization wedges: solving the climate problem for the next 50 years with current technologies.Science305, 968-972. DOI: 10.1126/science. 1100103) 
[39.] Picard JF, Magnussen S, Banack NL, Namkosserena S, Yalibanda Y (2010) Permanent sample plots for natural tropical forest: a rational with special emphasis on Central Africa. Environmental monitoring and assessment 164 (1): 279-295. DOI: 10.1007/s10661-009-0892-y.

[40.] Schrag DP (2007) Preparing to capture carbon. Science 315: 812-813. DOI: 10.1126/science.1137632.

[41.] Sicard P, Dalstein-Richier L (2015) Health and vitality assessment of two common pine species in the context of climate change in Southern Europe. Environmental Research 137:235-245.

[42.] Tans P P, Fung I Y, Takahashi T (1990) Observational constraints on the global atmospheric CO2 budget. Science247, 1431-1438. DOI: 10.1126/science.247.4949. 1431.

[43.] Timilsina N, Escobedo FJ, Staudhammer C L, Brandeis T (2014) Analyzing the causal factors of carbon stores in a subtropical urban forest. Ecological Complexity 20: 23-32

[44.] Wafo G (2008) : Les aires protegées de 1'Extrême-Nord Cameroun entre politique de conservation et pratiques locales, Thèse Doctorat en Géographie AménagementEnvironnement, Université d'Orléans. 325 p.

[45.] Walsh B (2007) Greenhouse airlines: traveling by jet is a dirty business. As passenger load increases, enviros look for ways to cut back the carbon. Time. $57 \mathrm{p}$.

[46.] Wang H, Liu S, Mo J, Wang J, Makeschin F, Wolff M (2010) Soil organic carbon stock and chemical composition in four plantations of indigenous tree species in subtropical China. Ecological Restoration 25:1071-1079

[47.] Zapfack L, Noiha NV, Dziedjou KPJ, Zemagho L, Fomete NT (2013) Deforestation and Carbon Stocks in the Surroundings of Lobéké National Park (Cameroon) in the Congo Basin. Environment and Natural Resources Research 3(2): 78-86.

[48.] Zapfack L, Chimi DC, Noiha NV, Zekeng JC, Meyan-ya DGR, TMRB (2016) Correlation between associated trees, cocoa trees and carbon stocks potential in cocoa agroforests of Southern Cameroon. Sustainability in Environment1 (2): 2470-6388. 